DOI: https://doi.org/10.47405/mjssh.v6i7.921

\begin{tabular}{|c|c|}
\hline 4 & Malaysian Journal of Social Sciences and Humanities (MJSSH) \\
\hline $\begin{array}{l}\text { Malaysian Journa of } \\
\text { Social cciences and }\end{array}$ & Volume 6, Issue 7, July 2021 \\
\hline (MJ-sSH) & e-ISSN : 2504-8562 \\
\hline & $\begin{array}{l}\text { Journal home page: } \\
\text { www.msocialsciences.com }\end{array}$ \\
\hline
\end{tabular}

\title{
Mispronunciation of High Front and Low Hausa Vowels among the Yorùbá Speakers
}

\author{
Sale Maikanti¹, Jurgen Martin Burkhardt², Yong Mei Fung³, Salina Binti Husain'1, olúwadọrọ̀ \\ Jacob Oludare 4 \\ 1Department of Foreign Languages, Faculty of Modern Languages and Communication, \\ Universiti Putra Malaysia (UPM) \\ 2Sunway College Malaysia \\ 3Department of English, Faculty of Modern Languages and Communication, \\ Universiti Putra Malaysia (UPM) \\ ${ }^{4}$ Department of Linguistics and African Languages, Faculty of Arts, \\ University of Ibadan, Nigeria \\ Correspondence: Sale Maikanti (maikanti86@gmail.com)
}

\begin{abstract}
Pronunciation in second language learning is sometimes challenging, especially the vowels. Vowels such as [i] and [a] are found both in Hausa and Yorùbá but [i:] and [a:] are peculiar to Hausa alone. While Hausa has short and long vowels, Yorùbá has only oral and nasal vowels in their vowel inventories. Such phonemic differences constitute learning challenges, especially for the Yorùbá native speakers. This is a cross-sectional study design using mixed methods to examines the production of high front vowels: [i], and [i:], as well as low: [a], and [a:] Hausa vowels by the Yorùbá speakers to identify which group perform better between group 1 (Yorùbá native speakers who learned Hausa in the secondary school before going to the college of education), and group 2 (Yorùbá native speakers who learned Hausa informally before going to the college of education). The study also seeks to find out vowel substitutions that occur in the pronunciation tasks using 80 participants from 18 years old and above from the College of Education system in Nigeria who were selected based on purposive sampling. The findings were discussed in line with Flege \& Bohn's (2020) 'Revised Speech Learning Model'. 8 stimuli were audio-recorded, transcribed, and rated by two independent raters, in addition to participant observation techniques adapted. The results of the Mann-Whitney test revealed that group 2 performed better than group 1 . The study discovered also that the short [a] in the first and second syllables had the highest frequency of substitution compared to [i], [i:] and [a:] vowels. Such problems have pedagogical implications for learning Hausa as a second language.
\end{abstract}

Keywords: language, learning, vowels, mispronunciation, Yorùbá

\section{Introduction}

Second language learners find it a challenge to transmit messages effectively to listeners without proper pronunciation and intonation, regardless of how familiar they are with the structures and rules of the target language, especially due to the difference between the first and second languages. Flege, Bohn, \& Jang (1997) observe that most individuals who are learning a second language speak with a detectable foreign accent, which affects their pronunciation. Hausa and Yorùbá are spoken in different regions in Nigeria for educational, socio-economic, socio-political and socio-cultural purposes. 
Learning Hausa as a second language by Yorùbá native speakers is somehow difficult without learning the basic rudiments of the language, especially the high and low vowels. This is because one of the major factors in determining the accurate pronunciation of words in a language is how vowels are pronounced differently in the second language (L2) in comparison to L1 (Ata, 2015; Cox, 2006; Deterding, 1997; 2003; Ferragne \& Pellegrino, 2010; Hillenbrand, Getty, Clark \& Wheeler, 1995; Mutonya, 2008; Pillai, Mohd, Knoles \& Tang, 2010; Sharbawi, 2006). As vowels form the foundation and the nuclei in the production of syllables and words, they are also regarded as an important phonological aspect of tonal languages since the meaning of a word is dependent on vowels (Shehu \& Njidda, 2016). Maiunguwa (2015) adds that the majority of the L2 learners are not comfortable whenever they are misunderstood due to errors in their pronunciations. This is because pronunciation has long been considered one of the most important indicators of how well L2 learners understand the target language, as well as it determines how L2 learners are accepted by the L1 native speakers. Munro and Derwing (1995) argue that the closer the pronunciation of a learner to that of a native speaker, the easier it is when it comes to understanding the message.

Hausa and Yorùbá are two of Nigeria's three major languages, with Hausa serving as a lingua franca in northern Nigeria, and Yorùbá as a lingua franca in the south-west of Nigeria. Areas, where Hausa is spoken, include parts of the West African sub-region, the western world, such as the United States of America, Great Britain, Germany, and parts of Asia, with a current population of speakers in Nigeria of 53,700,000. 00 (Gordon, 2005; Eberhard, Gary, \& Charles, 2020). The Yorùbá people specifically in the South-West of Nigeria speak Yorùbá language. The fact that Yorùbá belongs to the NigerCongo language family (Blench, 2019), around sixty million people speak the Yorùbá language across the Niger for socio-economic, cultural and political developments (Adesola, 2005; Blench, 2014; Fábùnmi, 2010). Olúwadọrọ̀ \& Abiola (2016), Maikanti, Thai, Burkhardt, Fung, Husain, \& Olúwadọro (2021) also add that Yorùbá is spoken in areas such as Edo, Delta, Kwara and parts of Kogi States in Nigeria. Therefore, both Hausa and Yorùbá have a reasonable number of speakers each in Nigeria, as well as other parts of West African countries (Olusola, 2015).

While standard Hausa has five pairs of monophthongs which comprised of 5 short vowel phonemes such as [i], [e], [a], [o], [u]; 5 long vowel phonemes: [i:], [e:], [a:], [o:], [u:], and 2 diphthong phonemes: [ai] and [au] (Sani 2005, 2007), the standard Yorùbá on the other hand, has 7 oral vowel

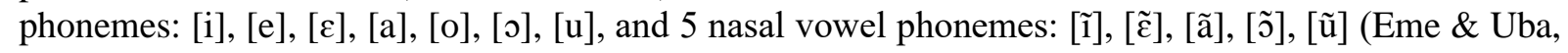
2016; Maikanti, Thai, Burkhardt, Fung, Husain, \& Olúwadọro, 2021). Hausa and Yorùbá shared five (5) oral monophthongs phones: [i], [e], [a], [o], [u]. While Yorùbá has two extra vowels which are $[\varepsilon]$ and [o], Hausa on the other hand, has two diphthongs, [ai] and [au], which Yorùbá does not possess. Moreover, Hausa has a phonemic distinction between short versus long among these five vowels whereas vowel length differences are only phonetic in Yorùbá. The latter has five nasal vowel

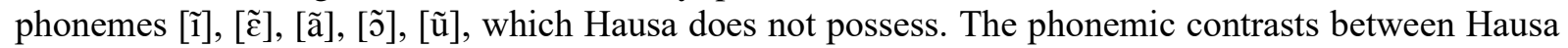
and Yorùbá made it difficult for the Yorùbá native speaker to produce the Hausa vowels correctly. The purpose of this research was to look into the production of [i], [i:], [a], and [a:] Hausa vowels in the pronunciation of disyllabic Hausa words in the first and second syllables among the Yorùbá native speakers. The study compares the performance of group 1- Yorùbá native speakers who learned Hausa formally in the secondary school before going to the college of education, and group 2- Yorùbá native speakers who learned Hausa informally before going to the college of education to identify which group perform better in pronunciation.

\section{Literature Review and Theoretical Basis}

Extant literature on second language learning (Ahmad \& Botne, 1992, Cowan \& Schuh, 1976; Furniss, 1991; Jaggar, 1992; 1996; Kraft \& Kirk-Greene, 1973; Kraft \& Kraft, 1973; Maikanti, 2003; Maikanti, Shu'aibu, \& Uba, 2013; Skinner, 1972) have focused more on Hausa alphabets, greeting system, counting system, names of body parts, none of such works has addressed the problem of mispronunciation, especially by the Yorùbá native speakers. To date, except Ibrahim (2000) who compared Hausa with Yorùbá in terms of gender usage, other studies on Hausa (Abubakar, 2014; Keshavarz \& Khamis, 2017; Mahmoud, 2017; Salisu \& Grema, 2018), as well as studies on Yorùbá 
(Babarinde, 2017; Eme \& Uba, 2016; and Olusola, 2015) reflect the paucity of research with respect on the pronunciation of front-high and low Hausa vowels by the Yorùbá native speakers. The majority of Hausa research (Abubakar, 1999; Baba, 1998; Fagge, 2012; Jaggar, 2001; Newman, 1995; 2000) centre on Hausa L1 phonology, with little attention paid to Hausa L2 phonology. Furthermore, studies (e.g. Qin \& Mok, 2013; So, 2010; So \& Best, 2010; Wu, Munro \& Wang, 2014; Yang, 2018) were related to speech sound perception, rather than studies on productivity. Research that focuses solely on production, such as the pronunciation of Hausa vowels by the Yorùbá native speakers, is relatively scarce.

Although there are numerous theories on second language learning (e.g., Lado's (1957) Contrastive Analysis Hypothesis; Corder's (1967) Error Analysis Model; Best's (1994, 1995); Flege's (1995); Best \& Tyler's (2007) Perceptual Assimilation Model for Second Language; and Flege \& Bohn's (2020) Revised Speech Learning Model), the postulation of Flege \& Bohn's (2020) 'SLM-r' best predicts the outcome of the present research. While theories such as 'PAM'- Best $(1994,1995)$, 'PAM-L2'- Best $\&$ Tyler (2007) centre on the perception of native and non-native speech sounds, they also discuss the types and causes of errors in L2 learning. The 'SLM-r' therefore, argues that second language learners have more problems with the sounds that are shared between the L1 and L2, while the unshared sounds are easy for the L2 learners to produce. The fact that the present study is on production task, the postulations of 'SLM-r' on how some participants could pronounce the front high and low Hausa vowels correctly, while some participants mispronounce the vowels, appeared to be the best option for this research. The findings of this study contributes to the formal and informal teaching and learning of Hausa as a second language, particularly in the Nigerian school system. The non-Hausa speakers (such as Nupe, Gwari, Fulfulde, and Yorùbá) who share boundaries with Hausa land would also be encouraged to learn Hausa as a second language. This is in addition to assisting the learners to understand how to read, write, and speak Hausa fluently for effective communication.

\section{Methods}

Since the present study is a cross-sectional design whereby one of the researchers measure the outcome and the exposure of the participants using mixed methods of data analysis, Babbie (1989) regarded this type of research as a 'one-shot' study. One of the aims of this type of design is to find out issues relating to the prevalence of a phenomenon, situation, problem, attitude or issue, by taking a cross-section of the population at one time (89). With this, Almalki (2016), Sileyew (2019) add that this type of approach allows the researcher to make detailed explanation concerning second language learning phenomena. 80 participants (40 students from each group) aged 18 years old and above who were learning from colleges education in the South-West of Nigeria were recruited based on purposive sampling. This figure represents the whole population of the students in the five schools (FCE OsieleAbeokuta, ACE Ondo, COE Ikere-Ekiti, FCE (Special) Oyo, and COE Oro) involved in the present research, which Creswell (2014) also suggests the use of all the population as a sample size, especially when the population in research is so small. Holton \& Bernett (1997) equally add that the ability to use a small number of participants to make inferences about larger groups is one of the advantages of the quantitative method of research. As such, all the participants were also screened to ensure that only the right participants (Yorùbá native speakers) were recruited. The study location consists of the following states in the southwest of Nigeria: Ekiti, Ondo, Oyo, Ogun, and the Kwara States.

Figure 1: Map of the study areas

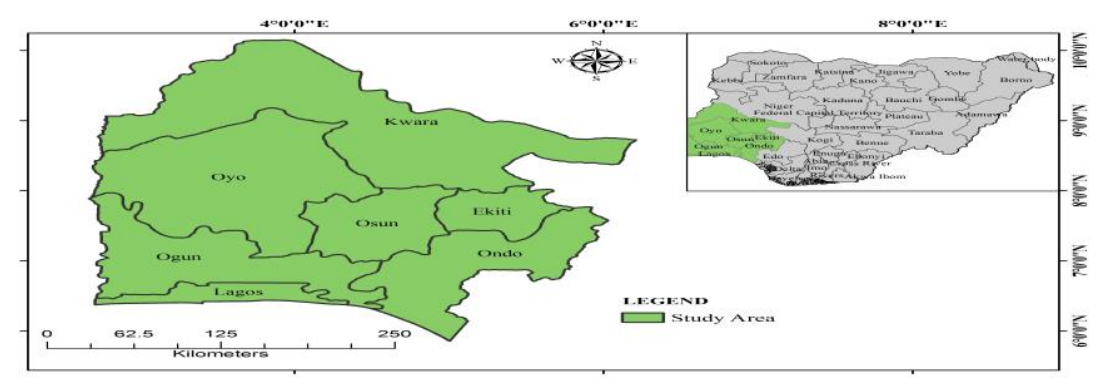


Western education in Nigeria has a long history. However, the 6-3-3-4 system of education in Nigeria which started in 1983 required the students to attend the following steps of education: 6-year primary education, 3-year junior as well as 3-year senior secondary education, and finally, the 4-year tertiary education. In all three stages of schooling, provisions were made for second language learning (Igbokwe, 2015; Uwaifo \& Uddin, 2009). Students who attend colleges of education were expected to among others, spend 3 years to acquire the minimum teaching qualification of National Certificate in Education (NCE) to qualify them to teach in either primary or secondary school, in the absence of L1 Hausa teachers (Nigeria Certificate in Education Minimum Standards for Languages, 2020; National Policy on Education, 2004). In this study, participants in group 1 were categorised as students who learned Hausa in secondary school but admitted to the college of education to further learn Hausa as a second language. Participants in group 2 were categorised as students who only acquired Hausa on the street, and they were also admitted to the college of education to study Hausa as a second language. Ethical approval was granted by the relevant authority before the data collection in line with Leedy \& Ormrod (2005). Since participation in the present study was voluntary, participants were informed in writing that the data they provided was for research, and they had the right to withdraw from the study at any time without any implication. This is in addition to the assurance given to them that all their identities, including the information they provided, would be kept confidential. They were also informed that data collected from them would be kept in retrieval storage. Those who agreed to participate in the study were made to sign a consent form before they participated in the research.

Eight wordlists comprised of target and non-target vowels prepared in carrier phrases were used as research instruments for this study. The stimuli used in the present research with CV.CVV and CVV.CV syllable patterns account for each vowel in the first and second syllables. For instance, while ' gídá' had a short [i] in the first syllable, 'gádi' had a similar short [i] in the second syllable. This is similar to where 'bità' had a long [i:] in the first syllable, 'fârí had a similar long [i:] in the second syllable.) Since the study investigates the mispronunciation of vowels in the first and second syllables of Hausa words, only disyllabic Hausa words were selected for this study. The reason for putting the wordlist in carrier phrases was to let the participants to read the stimuli as freely as they wanted in their normal pronunciation without recognising the exact items being studied by the researchers. Thus, they didn't have to make an extra effort with the pronunciation. Each vowel was also assigned a tone for easy identification while reading the stimuli, and the participants were given enough time to complete the pronunciation task. In line with Stella (1985), Tailor (1992) who recommended that speech recordings in research be conducted in a sound-proof to eliminate background noises, the speech sounds of the participants were audio-recorded by one of the researchers in the language laboratories. Scoring were done independently by the two Hausa native speakers and linguists, who awarded ' 1 ' mark each for the correct pronunciation, and ' 0 ' mark for the wrong pronunciation. The inter-rater reliability was carried out using Pearson Correlation $d$ to determine the level of agreement between the two raters. One of the researchers transcribed the pronunciation tasks performed by the participants to determine the substitution that took place. The fact that the data was not normally distributed in line with Skewness and Kurtosis K-values for not falling within the acceptable range of \pm 1 to \pm 2 (George \& Mallery, 2003; Rovain, Baker, and Ponton, 2013), a Mann-Whitney U test was conducted to compare the performance of the two groups in the pronunciation tasks.

\section{Results Analysis}

\section{Pronunciation of [i] and [i:] in the first syllable}

To determine whether there is a significant difference in pronunciation performance between group 1 Yorùbá native speakers who learned Hausa formally (in secondary school before attending a college of education) and group 2 - Yorùbá native speakers who learned Hausa informally (before attending a college of education), it was decided to use the Mann-Whitney U test. Participants' proficiency in pronouncing the [i] vowel was examined between groups 1 and 2 . The findings demonstrated that there was no statistically significant difference in performance between the two groups when it came to producing short [i] in the first syllable $(\mathrm{U}=740 ; p=.079)$. The mean rank indicated that the Yorùbá native speakers who learned Hausa informally before going to the college of education performed slightly better than the Yorùbá native speakers who learned Hausa formally before going to the college 
of education to learn Hausa as a second language. A Mann-Whitney U test indicated that there was a significant difference between the two groups compared in terms of the production of long [i:] vowel in the first syllable $(\mathrm{U}=280 ; p<.001)$. The mean rank shows that the Yorùbá native speakers who learned Hausa informally before going to the college of education performed much better than their counterparts who learned Hausa in the secondary school before going to the college of education. Table 1 summarises the results of the two groups based on the production of [i] and [i:] vowels in the first syllable:

Table 1: Mean Rank for [i] and [i:] in the first syllables

\begin{tabular}{lllll}
\hline & Group of participants & N & Mean scores & Sum of Ranks \\
\hline Short [i] & Gr 1 & 40 & 39.00 & 1560.00 \\
& Gr 2 & 40 & 42.00 & 1680.00 \\
Long [i:] & Gr 1 & 40 & 27.50 & 1100.00 \\
& Gr 2 & 40 & 53.50 & 2140.00 \\
\hline
\end{tabular}

The results presented in table 1 indicated that the mean ranks for the pronunciation of [i] vowel by participants in group 2 in the first syllable was better compared to the performance of group 1 . Similarly, the mean rank for the pronunciation of [i:] vowel by participants in the first syllable by group 2 was also better than the performance of participants in group 1.

\section{Pronunciation of [a] and [a:] in the first syllable}

According to the results of the Mann-Whitney $U$ test, there is no significant difference between the two groups' performance in producing the short $[\mathrm{a}]$ in the first syllable $(\mathrm{U}=740 ; p=.502)$. The mean rank indicates that the Yorùbá native speakers who learned Hausa informally before going to the college of education performed slightly better than the Yorùbá native speakers who learned Hausa in the secondary school before going to the college of education. The Mann-Whitney $U$ test was also used to evaluate the two groups' performance, and the results demonstrate that there is a significant difference in the pronunciation of the long [a:] in the first syllable $(\mathrm{U}=620 ; p<.002)$. The mean rank reveals that the Yorùbá native speakers who learned Hausa informally before going to the college of education performed better than the Yorùbá native speakers who learned Hausa in secondary school before going to the college of education. The summary of results of the two groups based on the pronunciation of [a] and [a:] vowels in the first syllable are presented in Table 2 below:

Table 2: Mean Rank for [a] and [a:] in the first syllables

\begin{tabular}{lllll}
\hline & Group of participants & N & Mean scores & Sum of Ranks \\
\hline Short [a] & Gr 1 & 40 & 39.00 & 1560.00 \\
& Gr 2 & 40 & 42.00 & 1680.00 \\
Long [a:] & Gr 1 & 40 & 36.00 & 1440.00 \\
& Gr 2 & 40 & 45.00 & 1800.00 \\
\hline
\end{tabular}

The results in table 2 revealed that the mean ranks for the production of [a] vowel by participants in group 2 in the first syllable was better than the performance of group 1. Similarly, the mean rank for the production of [a:] vowel by participants in the first syllable by group 2 was also better than the performance of participants in group 1 .

\section{Pronunciation of [i] and [i:] in the second syllable}

The Mann-Whitney $U$ test indicates that pronouncing the short [i] in the second syllable differs statistically and significantly $(\mathrm{U}=540 ; p<.002)$ between the two groups. The mean rank revealed that Yorùbá native speakers who learned Hausa informally before going to the college of education performed significantly better than the Yorùbá native speakers who learned Hausa in the secondary school before going to the college of education. According to the Mann-Whitney $U$ test, there is no statistically significant difference between the two groups' performance in pronouncing the long [i:] in 
the second syllable $(\mathrm{U}=760 ; p<.308)$. However, the mean rank reveals that the Yorùbá native speakers who learned Hausa informally before going to the college of education performed slightly better than the Yorùbá native speakers who learned Hausa in the secondary school before going to the college of education. Table 3 summarises the results based on the production of [i] and [i:] vowels in the second syllable:

Table 3: Mean Rank for [i] and [i:] in the second syllables

\begin{tabular}{lllll}
\hline & Group of participants & N & Mean scores & Sum of Ranks \\
\hline Short [i] & Gr 1 & 40 & 34.00 & 1360.00 \\
& Gr 2 & 40 & 47.00 & 1880.00 \\
Long [i:] & Gr 1 & 40 & 39.50 & 1580.00 \\
& Gr 2 & 40 & 41.50 & 1660.00 \\
\hline
\end{tabular}

Table 3 shows that the mean ranks for the pronunciation of [i] in the second syllable by participants in group 2 were higher than the performance of group 1. Similarly, the mean ranks for participants in group 2 also in the pronunciation of [i:] vowel in the second syllable was higher than that of group 1 .

\section{Pronunciation of [a] and [a:] in the second syllable}

The Mann-Whitney U test demonstrates a significant difference in the pronunciation of short [a] in the second syllable between the two groups $(\mathrm{U}=620 ; p<.044)$. The mean rank shows that Yorùbá native speakers who learnt Hausa informally before attending a college of education did much better than Yorùbá native speakers who learned Hausa in the secondary school before attending a college of education. The Mann-Whitney $U$ test found that there is a statistically significant difference between the two groups in the pronunciation of long [a:] in the second syllable $(\mathrm{U}=720 ; p<.041)$. The mean rank also shows that Yorùbá native speakers who learnt Hausa informally before attending a college of education scored much better than the Yorùbá native speakers who learned Hausa in secondary school before attending a college of education. Table 4 summarised the findings of the two groups in the production of the [a] and [a:] vowels in the second syllable:

Table 4: Mean Rank for [a] and [a:] in the second syllables

\begin{tabular}{lllll}
\hline & Group of participants & N & Mean scores & Sum of Ranks \\
\hline Short [a] & Gr 1 & 40 & 36.00 & 1440.00 \\
& Gr 2 & 40 & 45.00 & 1800.00 \\
Long [a: & Gr 1 & 40 & 38.50 & 1540.00 \\
& Gr 2 & 40 & 42.50 & 1700.00 \\
\hline
\end{tabular}

Table 4 showed that the mean rank for the pronunciation of short [a] in the second syllable by participants in group 2 was higher than the performance of group 1. Similarly, the mean rank for participants in group 2 in the pronunciation of long [a:] in the second syllable was also higher than that of participants in group 1. All of these are examples of the two groups' pronunciation errors. Table 5 summarises the quantitative results of the two groups in the production of the Hausa [i], [i:], [a], and [a:] vowels by Yorùbá speakers learning Hausa as a second language:

Table 5: Summary of performance for high, front, and low central vowels

\begin{tabular}{lllllll}
\hline Syllable & $\begin{array}{l}\text { High } \\
\text { vowel }\end{array}$ & $\boldsymbol{p}$ & Sig. & $\begin{array}{l}\text { Central } \\
\text { vowel }\end{array}$ & $\boldsymbol{p}$ & Sig. \\
\hline First & {$[\mathrm{i}]$} & .079 & No & {$[\mathrm{a}]$} & .502 & No \\
$״$ & {$[\mathrm{i}:]$} & .001 & Yes & {$[\mathrm{a}:]$} & .002 & Yes \\
Second & {$[\mathrm{i}]$} & .002 & Yes & {$[\mathrm{a}]$} & .044 & Yes \\
, & {$[\mathrm{i}:]$} & .308 & No & {$[\mathrm{a}:]$} & .041 & Yes \\
\hline
\end{tabular}


The fact that the substitution is a sound replacement process in which one sound replaces another in the same environment, it can also be linked to word mispronunciation in second language learning. Adekunle (2014) adds that when sounds are realised as different phonemes in pronunciation, such sounds manifest some kinds of changes at the segmental level. The substitutions that took place resulted to mispronouncing of some disyllabic Hausa words by the Yorùbá native speakers, taking into account the high front and low vowels in the first and second syllables. The substitutions made by the participants in this study are shown in Tables 6 to 9 . Any substitution less than 4 is considered trivial and treated as a performance error, whereas substitution from 4 and above is recognised as a competence error, especially when done by the Yorùbá participant. Note. While the Hausa vowels were underlined, and the Yorùbá vowels being italicised, the shared vowels were therefore bolden, and a dash signifying no substitution took place.

Table 6: Group 1 vowel substitution in the first syllable

\begin{tabular}{|c|c|c|c|c|c|c|c|c|c|c|c|c|c|c|c|c|c|c|c|}
\hline Vowel & i & i: & e & e: & $\mathbf{a}$ & a: & o & o: & $\mathbf{u}$ & u: & ai & au & $\varepsilon$ & o & $\tilde{\mathbf{i}}$ & $\tilde{\boldsymbol{\varepsilon}}$ & $\tilde{\mathbf{a}}$ & $\tilde{\mathbf{j}}$ & $\tilde{\mathbf{u}}$ \\
\hline [i] & - & 1 & 1 & - & 1 & - & - & - & - & - & - & - & - & - & - & - & & 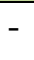 & - \\
\hline [i:] & $\begin{array}{l}2 \\
3\end{array}$ & - & 1 & - & - & 2 & - & - & - & - & - & - & - & - & - & 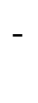 & & - & \\
\hline [a] & - & - & 1 & - & - & $\begin{array}{l}1 \\
6\end{array}$ & - & - & - & - & 1 & - & - & - & - & - & 1 & - & - \\
\hline [a:] & - & - & - & - & 4 & - & 1 & - & 1 & - & 1 & - & - & 1 & - & - & 1 & - & \\
\hline
\end{tabular}

The error counts in Table 6 were converted into percentages, with the most frequent occurrence at the top and the least frequent occurrence at the bottom of the ranking. As observed from the results, the long, high, front, unrounded vowel [i:] show the highest frequency of substitution. It was found to be substituted with the short, high, front, unrounded vowel [i] 23 times (57.5\%). This was considered high and needs to be addressed in Hausa language instruction to reduce potential miscommunication due to mispronunciation. The short open central vowel [a] was replaced with the long open central vowel [a:] 16 times (40\%). The long open central vowel [a:] was substituted with the short, open, central vowel [a] 4 times (10\%). These figures also point to competence errors and need to be tackled for better performance of the learners in second language learning.

Other substitution cases recorded in Table 6 range between 1 and 2 also point to performance errors due to their infrequent occurrence. Such infrequent substitutions that occurred in the present study are related to group 1, especially in the first syllable, which includes: short [i] was substituted with the long [i:] once, with short [e] once, and with short [a] once, each representing $2.5 \%$ of group 1 participants. For the long [i:], the following infrequent substitutions were observed: It was replaced with short [a] twice, amounting to $5 \%$ of group 1 participants, and with short [e] once, which represents $2.5 \%$. Also in group 1, the first syllable short [a] was substituted with [ai] diphthong only once, with short [e] once, and with [ã] also once, each representing $2.5 \%$. In addition, the long [a:] was replaced with [ai] diphthong, [o], [0], [u], as well as [ã] once each, with $2.5 \%$ for every representation.

Table 7: Group 2 vowel substitution in the first syllable

\begin{tabular}{llllllllllllllllllll}
\hline Vowel & i & i: & e & e: & a & a: & o & o: & u & u: & ai & au & $\boldsymbol{\varepsilon}$ & o & $\tilde{\boldsymbol{l}}$ & $\tilde{\varepsilon}$ & $\tilde{\boldsymbol{a}}$ & $\tilde{\boldsymbol{j}}$ & $\tilde{\boldsymbol{u}}$ \\
\hline$[\mathrm{i}]$ & - & - & - & - & - & - & - & - & - & - & - & - & - & - & - & - & - & - & - \\
[i: $]$ & - & - & - & - & - & - & - & - & - & - & - & - & - & - & - & - & - & - & - \\
{$[\mathrm{a}]$} & - & - & - & - & - & 8 & - & 12 & - & - & - & - & - & - & - & - & - & - & - \\
[a:] & - & - & - & - & - & - & - & - & - & - & - & - & - & - & - & - & - & - & - \\
\hline
\end{tabular}

Table 7 shows the error counts for the substitutions of vowels by participants in group 2. The short open central vowel [a] was substituted with the long open central vowel [a:] 8 times, representing $20 \%$. The short open central vowel [a] was substituted with the long mid-back rounded vowel [o:] 12 times, the figure representing $25 \%$. 
DOI: https://doi.org/10.47405/mjssh.v6i7.921

Table 8: Group 1 vowel substitution in the second syllable

\begin{tabular}{llllllllllllllllllll}
\hline Vowel & $\mathbf{i}$ & $\underline{\mathbf{i}}$ & $\mathbf{e}$ & $\underline{\mathbf{e}}:$ & $\mathbf{a}$ & $\underline{\mathbf{a}} \mathbf{i}$ & $\mathbf{0}$ & $\underline{\mathbf{0}}$ & $\mathbf{u}$ & $\underline{\mathbf{u}}$ & $\underline{\mathbf{a i}}$ & $\underline{\mathbf{a u}}$ & $\boldsymbol{\varepsilon}$ & $\boldsymbol{\jmath}$ & $\boldsymbol{\boldsymbol { i }}$ & $\tilde{\boldsymbol{\varepsilon}}$ & $\tilde{\boldsymbol{a}}$ & $\tilde{\boldsymbol{j}}$ & $\tilde{\boldsymbol{u}}$ \\
\hline [i] & - & 9 & - & - & - & 10 & - & - & - & - & - & - & - & - & - & - & - & - & - \\
[i:] & 1 & - & - & - & 1 & 1 & - & - & - & - & - & - & - & - & - & - & - & - & - \\
[a] & - & - & - & 2 & - & 19 & - & 1 & - & - & - & - & - & - & - & - & - & - & - \\
[a: $]$ & - & - & 1 & - & 1 & - & 1 & 1 & - & - & - & - & - & - & - & - & - & - & - \\
\hline
\end{tabular}

Table 8 shows the types and numbers of substitutions for group 1 in the second syllable of the tested disyllabic Hausa words pronounced by the participants. The short vowel [a] was observed to have been substituted with [a:] 19 times, which amounts to $47.5 \%$ of the group participants. The $47.5 \%$ error count as committed by the learners was significantly high and needs to be revisited for optimum performance in terms of second language learning. The short [i] was substituted with [i:] 9 times, which represents $22.5 \%$ of the entire number of participants in this group. Several participants in this group replaced [i] with [a:] 10 times, which represents $25 \%$. However, infrequent substitutions of second syllable vowels by participants of group 1 occurred. In this syllable, the long [i:] was substituted with long [a:], short [i], and short [a] 1 time each, amounting to $2.5 \%$ for every substitution made. The second syllable short [a] was also replaced with long [e:] two times, representing 5\% of group 1, and with long [o:] once, which represents $2.5 \%$. Finally, long [a:] was replaced with the long [o:], short [e], short [a], and short [o] one time each, amounting to $2.5 \%$.

Table 9: Group 2 vowel substitution in the second syllable

\begin{tabular}{llllllllllllllllllll}
\hline Vowel & $\mathbf{i}$ & $\underline{\mathbf{i}} \mathbf{i}$ & $\mathbf{e}$ & $\underline{\mathbf{e}:}$ & $\mathbf{a}$ & $\underline{\mathbf{a}:}$ & $\mathbf{o}$ & $\underline{\mathbf{o}}$ & $\mathbf{u}$ & $\underline{\mathbf{u}}$ & $\underline{\mathbf{a i}}$ & $\underline{\mathbf{a u}}$ & $\boldsymbol{\varepsilon}$ & $\boldsymbol{o}$ & $\tilde{\boldsymbol{i}}$ & $\tilde{\varepsilon}$ & $\tilde{\boldsymbol{a}}$ & $\tilde{\boldsymbol{\jmath}}$ & $\tilde{\boldsymbol{u}}$ \\
\hline [i] & - & 3 & - & 1 & - & 2 & - & - & - & - & - & - & - & - & - & - & - & - & - \\
[i:] & 2 & - & - & - & 1 & - & - & - & - & - & - & - & - & - & - & - & - & - & - \\
[a] & - & - & - & - & - & 15 & - & - & - & - & - & - & - & - & - & - & - & - & - \\
[a: $]$ & - & - & - & - & 1 & - & - & - & - & - & - & - & - & - & - & - & - & - & - \\
\hline
\end{tabular}

Table 9 shows the substitutions of second syllable Hausa vowels made by group 2 participants. In this case, only the substitution of [a] with [a:] is frequent, occurring 15 times, which represents $37.5 \%$ of the number of this group. As far as infrequent substitutions in are concerned, the short [i] was substituted with long [i:] 3 times (7.5\%), with long [e:] once (2.5\%), and with long [a:] twice (5\%). Second syllable long [i:] was replaced also with short [i] twice (5\%) and with short [a] once $(2.5 \%)$, while the long [a:] was replaced with short [a] only once $(2.5 \%)$.

\section{Discussion}

The study revealed that $p$ values of $[\mathrm{i}](\mathrm{U}=740 ; p>.079)$, [a] $(\mathrm{U}=740 ; p>.502)$ in the first syllable, as well as [i:] $(\mathrm{U}=760 ; p>.308)$ in the second syllable are statistically non-significant $(p>.05)$. On the other hand, the $p$ values of [i:] $(\mathrm{U}=280 ; p<.001)$ and [a:] $(\mathrm{U}=620 ; p<.002)$ in the first syllable, and those of [i] $(\mathrm{U}=540 ; p<.002)$, [a] $(\mathrm{U}=620 ; p<.044)$ and [a:] $(\mathrm{U}=720 ; p<.041)$ in the second syllable show a significant difference between the two groups. Several vowels were produced with some level of perfection, while some were produced with difficulties. The short [i] was produced with little or no error in the first syllable of group 1 but was substituted with long [i:] 9 times (22.5\%), and with [a:] 10 times (25\%). This is in contrast to replacements of long [i:] with [i] 23 (57.5\%), and [a] with [a:] (see tables 6, 7, 8 and 9). In terms of how the participants in group 2 produced the front high and low Hausa vowels, only the short [a] has a higher frequency of replacements with other vowels, but [i], [i:], and [a:] vowels have limited or no cases of erroneous substitution, particularly in the first syllable. As for group 2 performance in the second syllable, the data for this research revealed that long Hausa [i:] and [a:] also have little or no erroneous substitutions with other vowels, in contrast to the short Hausa [i] and [a] (high front and low) which exhibit a lot of erroneous substitutions by Yorùbá native speakers (see Table 8 serial number 1- 4 above). The erroneous vowel substitution of L1 sounds by L2 speakers usually have to do with differences in vowel inventory in different co- 
DOI: https://doi.org/10.47405/mjssh.v6i7.921

occurrence restrictions of vowels and different types of tones and tonal patterns between L1 and L2. However, Table 10 illustrates erroneous vowel replacements with their numbers based on negative inference from L1 on L2 (i.e. Yorùbá to Hausa) pronunciation.

Table 10: Phoneme realisations by the participants in group $1 \& 2$

\begin{tabular}{llllll}
\hline Hausa & $\begin{array}{l}\text { Group 1 } \\
\text { First }\end{array}$ & $\begin{array}{l}\text { Second } \\
\text { syllable }\end{array}$ & $\begin{array}{l}\text { Group 2 } \\
\text { First } \\
\text { syllable }\end{array}$ & $\begin{array}{l}\text { Second } \\
\text { syllable }\end{array}$ & $\begin{array}{l}\text { Non-replaced } \\
\text { vowels }\end{array}$ \\
\hline$[\mathrm{i}]$ & $*$ & {$[\mathrm{a}:],[\mathrm{i}:]$} & $*$ & $*$ & 3 \\
{$[\mathrm{i}:]$} & {$[\mathrm{i}]$} & $*$ & $*$ & $*$ & 3 \\
{$[\mathrm{a}]$} & {$[\mathrm{a}:]$} & {$[\mathrm{a}:]$} & {$[\mathrm{o}:],[\mathrm{a}:]$} & {$[\mathrm{a}:]$} & 0 \\
{$[\mathrm{a}:]$} & {$[\mathrm{a}]$} & $*$ & $*$ & $*$ & 3 \\
\hline
\end{tabular}

Table 10 indicated vowels that were substituted, and the ones substituted with, in the first and second syllables. Meanwhile, the asterisk * denoted that no substitution had taken place. It also showed that Hausa phonemes were correctly pronounced depending on the syllable. Thus, certain disyllabic Hausa words were mispronounced, and have their meaning changed according to learner pronunciation. Table 11 and 12 below illustrate how some Hausa words were realised:

Table 11: Realised Hausa words by group 1 participants

First syllable

\begin{tabular}{|c|c|c|c|c|c|c|c|}
\hline $\mathbf{S} / \mathbf{N}$ & $\begin{array}{l}\text { Hausa } \\
\text { vowel }\end{array}$ & $\begin{array}{l}\text { Replaced } \\
\text { vowel }\end{array}$ & $\begin{array}{l}\text { Correct } \\
\text { pronunciation }\end{array}$ & $\begin{array}{l}\text { Real } \\
\text { meaning }\end{array}$ & $\begin{array}{l}\text { Leaner } \\
\text { pronunciation }\end{array}$ & $\begin{array}{l}\text { Old/New } \\
\text { meaning }\end{array}$ & No. \\
\hline 1. & [i] & $*$ & [gídá:] & home & *[gídá:] & home & 0 \\
\hline 2. & [i:] & [i] & [bí:tà] & revision & [bítà] & meaningless & 1 \\
\hline 3. & [a] & [a:] & [dákó:] & $\begin{array}{l}\text { carrying } \\
\text { load }\end{array}$ & [dá:kó:] & meaningless & 1 \\
\hline 4. & [a:] & [a] & [ná:mà:] & meat & **[námà:] & meat & 1 \\
\hline \multicolumn{8}{|c|}{ Second syllable } \\
\hline 1. & [i] & [a:], [i:] & [gá:dì] & guard & $\begin{array}{l}\text { [gádà:] } \\
* * \text { [gá:dì:] }\end{array}$ & $\begin{array}{l}\text { bridge } \\
\text { guard }\end{array}$ & 2 \\
\hline 2. & [i:] & $*$ & *[fârí:] & proud & *[fârí:] & proud & 0 \\
\hline 3. & [a] & [a:] & [Bà:gá] & $\begin{array}{l}\text { name of } \\
\text { town }\end{array}$ & **[Bà:gá:] & name of town & 1 \\
\hline 4. & [a:] & $*$ & *[tá:bà:] & cigarette & *[tá:bà:] & cigarette & 0 \\
\hline
\end{tabular}

Table 12: Realised Hausa words by group 2 participants

First syllable

\begin{tabular}{|c|c|c|c|c|c|c|c|}
\hline $\mathrm{S} / \mathrm{N}$ & $\begin{array}{l}\text { Hausa } \\
\text { vowel }\end{array}$ & $\begin{array}{l}\text { Replaced } \\
\text { vowel }\end{array}$ & $\begin{array}{l}\text { Correct } \\
\text { pronunciation }\end{array}$ & $\begin{array}{l}\text { Real } \\
\text { meaning }\end{array}$ & $\begin{array}{l}\text { Learner } \\
\text { pronunciation }\end{array}$ & $\begin{array}{l}\text { Old/New } \\
\text { meaning }\end{array}$ & No. \\
\hline 1. & [i] & $*$ & *[gídá:] & home & *[gídá:] & home & 0 \\
\hline 2. & [i:] & $*$ & *[bí:tà] & revision & *[bítà] & revision & 0 \\
\hline 3. & [a] & [o:], [a:] & [dákó:] & $\begin{array}{l}\text { carrying } \\
\text { load }\end{array}$ & $\begin{array}{l}\text { [Dó:kó:] } \\
\text { [dá:kó:] }\end{array}$ & $\begin{array}{l}\text { name of town } \\
\text { meaningless }\end{array}$ & 2 \\
\hline 4. & [a:] & $*$ & *[ná:mà:] & meat & *[ná:mà:] & meat & 0 \\
\hline \multicolumn{8}{|c|}{ Second syllable } \\
\hline 1. & [i] & $*$ & *[gá:dì] & guard & *[gá:dì] & guard & 0 \\
\hline 2. & [i:] & $*$ & *[fârí:] & proud & **[farí:] & proud & 0 \\
\hline
\end{tabular}


DOI: https://doi.org/10.47405/mjssh.v6i7.921

\begin{tabular}{llllllll}
\hline 3. & {$[\mathrm{a}]$} & {$[\mathrm{a}:]$} & [Bà:gá] & $\begin{array}{l}\text { name of } \\
\text { town }\end{array}$ & $* *$ [Bà:gá:] & name of town & 1 \\
4. & {$[\mathrm{a}:]$} & $*$ & $*$ [tá:bà:] & $\begin{array}{l}\text { cigarette } \\
\text { cigá:bà:] }\end{array}$ & cigarette & 0 \\
\hline
\end{tabular}

Tables 11 and 12 identified vowels that were replaced and the mispronunciation of Hausa words that occurred due to substitutions in the first and second syllables. Please note, * shows vowel was not substituted, and the meaning did not change. $* *$ indicates that vowel was substituted, and yet words retained their meaning.

Substituting [i] with [i:]: The low tone [i] is mispronounced as high tone [í:] in Hausa on the second syllable. This was evident in the data produced by group 1 participants, in which the short high low tone vowel [i] was replaced in the pronunciation of disyllabic Hausa words by the long, high, front, and unrounded [i:] vowel. For instance, the Hausa word [gá:dì] (HL) 'guard' was mispronounced as [gá:dí:] (HH). This is because Yorùbá has no phonemic vowel length distinction, and their vowels are phonetically optionally long in open final syllables. Eme \& Uba (2016) gives examples from Yorùbá with open final vowels to include: 'ori' [orí:] (head) 'idi' [ìdí:] (buttocks) and 'sìsi' [sìsí:] (young lady). Since vowel length is merely a phonetic variation in Yorùbá, word-final vowels can also be pronounced short with a glottalic closure in elicitation forms as in Yorùbá words 'akásì' [akásì] (a harpoon), and 'alámi' [alámì] (one having a mark). The erroneous lengthening of Hausa [ì] to [ì:] occurred because the word [gá:di] was uttered in a phrase. The consonant sound / $\mathrm{k} /$ that follows the high vowel is a glottal stop, and in rapid speech, the Yorùbá speakers mispronounce the phrase with a smooth transition without an intervening glottal stop, thereby lengthening [ì] to [í:].

Substituting [ì] with [à:]: The second syllable Hausa [ì] mispronounced as [à:] with low tone by the participants in group 1. For instance, the Hausa word [gá:dì] (HL) 'guard' was mispronounced as [gádà:] (HL) 'bridge' by the Yorùbá native speakers in their pronunciations (see Table 11 serial number 1). In this case, the entire meaning of such Hausa word is lost due to wrong pronunciation. The lengthening of the second syllable vowel can be explained not only due to vowel length, but also due to vowel quality/quantity from a front high to a mid-low vowel (with no change in tonal height). The mispronunciation of [gá:dì] to [gádà:] by Yorùbá speakers can as well be viewed as progressive assimilation where [á:-ì] vowel sequence changes to [á: - à:]. As observed from Yorùbá-English dictionary, the áCà: sequence is more frequent than the á:Cì combination, hence some Yorùbá speakers erroneously substituted [ỉ] with [à:]. Vowel assimilation as viewed in Crystal (1988) is a situation whereby a vowel in one part of a word influences the other vowel to have a similar articulation, even though there may be another sound between them (p.25). A similar type of assimilatory mispronunciation is reported in Salisu \& Grema (2018) who examined automatic assimilation of Hausa learners of the Bade language whereby assimilation took place between [i] and [a:], as [yìyà 'brother' in Bade language being mispronounced as [yàyà 'brother' by the Hausa speakers.

Substituting [í:] with [í]: The first syllable high tone Hausa [í:] mispronounced as [í] as evidenced from the data of this research led to mispronunciation from [bí:tà:] (HL) 'revision' to [bítà:] (HL), losing its original meaning. Such vowel replacement is linked to vowel shortening. The long sound was shortened in the environment of $* * *$ Cí:Cà changing to ***CíCà:. It can as well be attributed to the phonetic length variation of Yorùbá vowels which can be pronounced either long, medium-long or short. Similarly, the first syllable high tone [á] substituted by high tone [á:]. This is the case of erroneous lengthening to [á] in the environment from CV.CVV (***CáCó:) to CV:CV: (***Cá:Có: or ***Cá:Cò:) as the case may be. For instance, Hausa word such as [dákó:] (HH) 'carrying of load' was mispronounced [dá:kó:] (HH), or [dá:kò:] (HL) 'losing its meaning'. In this situation, vowel length which is phonemic in Yorùbá appears to be independent of tone, and vowel such as [á] is pronounced medium-long as indicated in the following Yorùbá words: 'adáwölé' [adá(a)wö(o)lé] (undertaker), 'bátóbàto' [bá(a)tó(o)bà(a)to(o)] (imperfectly), 'aládàrú' [alá(a)dàrú(u)] (a confounder), 'alágbàbö' [alá(a)gbà(a)bö(o] (nurse). An informant (Akingbola (2020)) who attest to the lengthening of /a/ in Yorùbá word-medial positions cited the following examples with HL tone sequence such as 'yáyi' [jàájī] (beauty/pretty), 'Tájù' [Tàádzù] (personal name), 'Sálè' [Sàálè] (personal name), and 'gbádùn' [gbàádì̀] 'enjoyment', which were also confirmed in Șowande's (1913) Yorùbá-English dictionary. All these factors also explained why some Yorùbá speakers erroneously lengthened Hausa first 
syllable non-high [a] by substituting it with [a:]. Hausa word such as [dàgà] 'from' was uttered as [dà:gà] 'not having a meaning', [bàdî] 'next year' also mispronounced as [bà:dí:] 'not having a meaning', as well as [tàfi:] 'go' mispronounced as [tà:fí:] or [tèfí:] 'go' are examples of such vowel replacements occurring in the pronunciation of Hausa words by the Yorùbá speakers.

Substituting [a] with [a:]: In the second syllable, [a] was pronounced [a:] is contained in the data. Hausa word such as [Bà:gáa (LH) 'name of a town' being mispronounced as [Bà:gá:] (LH) even though the meaning remains the same, the pronunciation has changed (refer to table 11, serial 3). According to Yorùbá convention, the pronunciation of vowels at the word-final position is relatively long regardless of tone (Eme \& Uba, 2016). As observed from the Yorùbá dictionary, the áCó (HH) (VCV) sequence has the lowest frequency in terms of word counts, compared to áCo (HM) and finally áCò (HL) with the highest frequency. The fact that Yorùbá words with áCò sequence have the highest frequency (word count) as contained in some Yorùbá examples such as 'abápò' [abákpò] (HL) (hammock), 'agbákò' [agbákò] (HL) (accident), and 'tinábò' [tinábò] (HL) (to set on fire) (Șowande, 1913), it can be concluded that the Yorùbá native speakers substitute the second syllable [ó] with [ò] according to Yorùbá phonotactics frequency.

Substituting [á] with [ó:]: Substituting the Hausa first syllable high tone [á] with high tone [ó:] by the participants may also be associated with vowel raising and Yorùbá phonotactics co-occurrence. Such erroneous substitution and lengthening of vowel (see section 5.1) changed its pronunciation as well as the meaning. Hausa words affected include [dákó:] 'carrying of load' mispronounced as [dó:kó:] 'meaningless' and [zágó:] as [zó:gó:] $(\mathrm{HH})$ 'large white ants'. The fact that Yorùbá words are invariably pronounced either with ***CáCó pattern such as 'fájó' [fádzó] (to burn), 'jámö [dzámö] (equal in value), and 'járö [ḑárö] (to discover a lie) or with ***CóCó, as in 'dógò' [dógò] (to dun for debt), 'kókò' [kókò] (an edible root), and 'tökõ' [tökõ] (to guide a ship), this explained the existence of the two patterns. So, the pronunciation mistake from [á] to [ó:] cannot be attributed to regressive vowel harmony phenomena. The pronunciation mistake is rather attributable to the rareness of ${ }^{*} \mathrm{CaCo}$ patterns, irrespective of tone in Yorùbá, whereas $* * * \mathrm{CoCo}$ (irrespective of tone) patterns are much more frequent in the language. These were confirmed from Sowande's (1913) Yorùbá-English dictionary with few numbers of Yorùbá words containing $* * *$ CaCo pattern, compared to words with ***CoCo syllable arrangement. The result obtained in this section is similar to Haruna (2008) who discovered the substitution of [a] with [o:] in Hausa words by Igbo speakers learning Hausa as a second language. According to Haruna, Hausa words such as [wátà:] was mispronounced as [wó:tà:] 'moon', and [wání] also mispronounced as [wó:ní] 'someone'. Similar to what was obtained in Mahmoud (2017), [a] was found to be substituted with [o:] in the pronunciation of Ebira native speakers, whereby Hausa words such as [wánká:] were mispronounced as [wónká:] 'bath', and [wàkílì] as [wòkílì] 'representative'.

Substituting [á:] with [á]: The first syllable high tone [á:] substituted with high tone [á] by the participants in group 1 was considered an erroneous shortening, especially in the syllable environments whereby $* * *$ Cá:Cà: changes to ${ }^{* * *}$ CáCà: pattern. Hausa word [ná:mà:] (HL) 'meat' was mispronounced as [námà:] 'meat'. This is because since Yorùbá does not have a long vowel, Yorùbá speakers learning a second language tend to substitute the difficult L2 sounds with the closest sounds to them in their mother tongue. Such a situation is what Olubode-Sawe (2010) considers as a case of reinterpretation whereby a phoneme is replaced with a source language phoneme for learning to progress. English word such as [gi 'ta:(r)] was mispronounced as [gitá] 'guitar'. Since vowel length is merely phonemic in Yorùbá, length variations in the pronunciation of vowels occur. This is because vowel initial nouns are never high-tone initial in Yorùbá (Akinlabi, 2007; Babarinde, 2015), and that Yorùbá vowels are sometimes pronounced neither short nor long, but somewhere in-between which could be regarded as mid-long pronunciation regardless of tone. The results in this study are in line with Samson, Abdullahi, \& Olagunju, (2014) who investigated the influence of Yorùbá as a mother tongue in the pronunciation of English sounds, whereby Yorùbá speakers replace English [a:] with [a] in the pronunciation of words such as [igzampl] instead of [igzæmpl] 'example', and [Igzəm] instead of [izam] 'exam'. In addition to that, Olubode-Sawe (2010) also discovered the substitution of [a:] with [a] in a word such as [gita:] mispronounced as [gitá] 'gitter' in Yorùbá. According to the study, it was a case of reinterpretation sounds where a phoneme is replaced with a source language phoneme which is readily available in the learners' mother tongue for a smooth learning process. 


\section{Implication}

The implication of continuous learning the pronunciation in error, the standard of Hausa will not only fall but will continue to be learnt in error. Therefore, this article recommends that pronunciations should be given priority attention in schools by making it a compulsory subject for all language-related courses starting from primary to tertiary level. The teaching of Hausa subjects in schools should be handled by only qualified Hausa language teachers. More emphasis should also be given to the teaching and learning of vowels. Well-equipped modern language laboratories should also be provided for effective second language learning in schools. In taking all these measures, the Yorùbá speakers learning Hausa as a second language will attain a high level of proficiency in the Hausa language.

\section{Conclusion}

Experts in language and linguistics have since recognised that learners' performance in the target language is invariably marked by faults, both in speech and in writing, as vowel production is a key component of second language learning. As a result, the discrepancy between L1 and L2 causes negative transfer errors in learning a second language. While the results of the quantitative analysis for the two groups were statistically not the same, the performance of individual participants also differs according to syllables. However, certain non-linguistic factors such as age, learners' attitude and individual differences, as well as a learning environment (Maikanti, Thai, Burkhardt, Fung, Husain, and Olúwadọro, 2021) all play significant roles in determining the performance of the two groups measured. As evidenced from the data, while the performance of the two groups in the pronunciation of [i], [a] (in the first syllable) and [i:] (in the second syllable) were not statistically significant of their p-value greater than .05 , the performance of the two groups based on the pronunciation of [i:], [a:] (first syllable), as well as [i], [a], and [a:] (second syllable) appeared statistically significant.

The findings of the present study align with Nhem (2019) who compared the performance of young learners and adolescent learners on language learning strategies where the results of the two groups are statistically not the same with their $\mathrm{p}$-value less than $(\mathrm{p}=.033)$. The findings also concur with the study in Chilkiewicz (2015) who also compared the mean scores of young learners $(M=18.75)$ with the adolescent learners $(M=17.46)$ in terms of language learning with the $p$-value less than $\mathrm{p} \leq .050$. While the general outcome of the present study support the predictions of Flege \& Bohn (2020) that the shared sounds between L1 and L2 are difficult for the Yorùbá speakers, learners of Hausa, the unshared sounds between the mother tongue and the target language are easier for the L2 learners to produce. Accordingly, the availability of particular sounds in the learner's mother tongue makes his brain to be less active in the processing of new sounds in the target language and vice versa. The fact that one of the researchers is a native speaker of Hausa, instances of mispronunciation were personally observed from the pronunciation of some non-Hausa speakers such as the case of pronouncing [bà:kó:] 'stranger', vs [Bà:kó] 'personal name, as well as [gàdá:] 'antelope' vs /Gàdál [Gàdá] 'name of a town'. The findings of the present study has been supported by the predictions of 'Revised Speech Learning Model' (SLM-r) which says that the challenges faced among the Yorùbá native speakers in terms of pronouncing some disyllabic Hausa words. Such challenges were due to the substitution of certain sounds with other sounds during pronunciation. Other factors responsible for the difficulties include vowel shortening, vowel lengthening, as well as over generalization of language rules.

\section{References}

Abubakar, A. (1999). Depalatalisation in Hausa: A generative approach. Maiduguri Journal of Linguistics and Literary Studies, 1, 1-19.

Abubakar M. K. (2014). Pronunciation problems of Hausa speakers of English: The case of Nigerian students in North Cyprus. Unpublished M.A. thesis, department of English language teaching, Near East Unversity.

Adekunle, O. G. (2014). Deviant realization of foreign vowels in the speech-form of Yorùbá-English Nigerian bilinguals. Open Journal of Modern Linguistics, 4, 720-727. 
Adesola, O. (2005). Yorùbá: A grammar sketch: Version 1.0. Rutgers University, USA.

Ahmad, M. \& Botne, R. (1992). Hausa reading kit: Graded text for elementary and intermediate university students. Bloomington: African Studies Program, Indiana University.

Akinlabi, A. (2007). Category change as vowel reduction: High vowels in Yorùbá. Tromso: Glowxxx.

Almalki, S. (2016). Integrating quantitative and qualitative data in mixed methods research. Journal of Educational and Learning, 5(3), 288-296.

Ata, M. I. (2015). An acoustic study of Nigerian English vowels produced by Hausa speakers. Unpublished M. A. dissertation, University of Malaya.

Baba, A. T. (1998). The Morpho-phonological alternations in the Hausa verbal form. Johann Wolfgang Goethe-Universität, Germany: Frankfurt/Main.

Babarinde, O. (2015). Knowledge of phonotactics constraints in Yorùbá: A necessary tactic behaviour for linguistic competence in the language. Language Matters: Studies in the Languages of Africa, 46(1), 60-80.

Babarinde, O. (2017). Nasalization in Yorùbá: The Onko dialect perspective. Unpublished $\mathrm{PhD}$ thesis, Department of linguistics, Igbo and other Nigerian languages, University of Nsukka, Nigeria.

Babbie, E. R. (1989). The practise of social research. Belmont, CA: Wadsworth Publishing Company.

Best, C. T., \& Tyler, M. D. (2007). Non-native and second-language speech perception: Commonalities and complementarities. In O-S, Bohn \& M. J. Munro (Eds.) Language Experience in Second Language Speech Learning: In Honour of James Emil Flege (pp. 13-34). Amsterdam \& Philadelphia: John Benjamins.

Best, C. T. (1994). The emergence of native-language phonological influences in infants: A perceptual assimilation model. The Development of Speech Perception: The Transition from Speech Sounds to Spoken Words, 167(224), 233-277.

Best, C. T. (1995). A direct realist of cross-language speech. In W. Strange (Ed.) Speech Perception and Linguistic Experience (pp. 171-204). Baltimore: York Press.

Blench, R. M. (2014). The origins of nominal affixes in MSEA languages: convergence, contact and some African parallels. Languages of Mainland South-East Asia: The State of the Art, 550-577.

Chilkiewicz, K. (2015). Direct language learning strategies in the theory by Rebecca Oxford in English vocabulary acquisition at the age group of 11-12-year-olds. World Scientific News, 7, 179-206.

Corder, S. P. (1967). The significance of learners' errors. International Review of Applied Linguistics, $5,160-170$.

Cowan, J. R. \& Schuh, R. G. (1976). Spoken Hausa. Ithaca: Spoken Language Services.

Cox, F. (2006). The acoustic characteristics of $/ \mathrm{hBd} /$ vowels in the speech of some Australian teenagers. Australian Journal of Linguistics, 26(2), 147-179.

Creswell, J. W. (2014). Research design: Qualitative, quantitative and mixed methods approaches (4th ed.). London: Sage Publications Ltd.

Crystal, D. (1988). A dictionary of linguistics and phonetics. New York: Basil Blackwell Ltd.

Deterding, D. (1997). The formants of monophthongs vowels in standard British English pronunciation. Journal of the International Phonetic Association, 27(1-2), 47-55.

Deterding, D. (2003). An instrumental study of the monophthongs vowels in Singapore English. English Worldwide, 24(1), 1-16.

Eberhard, D. M., Gary, F. S., and Charles D. F. (eds.) (2020). Ethnologue: Languages of the World. Twenty-third edition. Dallas, Texas: SIL International.

Eme, C. A., \& Uba, E. D. (2016). A contrastive study of the phonology of Igbo and Yorùbá. UJAH: Unizik Journal of Arts and Humanities, 17(1), 65-84.

Fábùnmi, F. A. (2010). Vigesimal numerals on Ifẹ̀ (Togo) and Ifẹ̀ (Nigeria)/Dialects of Yorùbá. Linguistik Online, 43(3/10), 1-44.

Fagge, U. U. (2012). Hausa language and linguistics. Zaria, Nigeria: Amadu Bello University Press Ltd.

Federal Republic of Nigeria (2004). National policy on education. Abuja: Ministry of Education.

Federal Republic of Nigeria (2020). Nigeria certificate in education minimum standards for languages. Abuja, Nigeria: National Commission for Colleges of Education (TETFund Project).

Ferragne, E., \& Pellegrino, F. (2010). Formant frequencies of vowels in 13 accents of the British Isles. Journal of the International Phonetic Association, 40(01), 1-34. 
Flege, J. E. (1995). Second language speech learning: Theory, findings, and problems. Speech Perception and Linguistic Experience: Issues in Cross-Language Research, 92, 233-277.

Flege, J. E., Bohn, O., \& Jang, S. (1997). Effects of experience on non-native speakers' production and perception of English vowels. Journal of Phonetics, 25(4), 437-470. Retrieved from https://doi.org/10.1006/jpho.1997.0052, on 16/6/2019.

Flege, J. E., \& Bohn, O. S. (2020). The revised speech learning model (SLM-r). https://www.researchgate.net/publication/342923320_The_revised_Speech_Learning_Model.

Furniss, G. (1991). Second level Hausa: Grammar in action. London: SOAS.

George, D., \& Mallery, M. (2003). Using SPSS for windows step by step: A simple guide and reference. Indiana University, USA: La Sierra University.

Gordon, R. G., JR. (ed.), (2005). Ethnologue: Languages of the World, Fifteenth Edition. Dallas, Texas: SIL International. Retrieved from online version: http://www.ethnologue.com/15,on $/ 10 / 2019$.

Haruna, M. H. (2008). Phonology in language II acquisition: The study of Igbo people living in sabongari speech community, acquiring Hausa as a second language. Unpublished M. A. thesis, department of Nigerian languages, Bayero University Kano, Nigeria.

Hillenbrand, J., Getty, L. A., Clark, M. J., \& Wheeler, K. (1995). Acoustic characteristics of American English vowels. Journal of the Acoustical Society of America, 97(5), 3099-3111.

Hodge, C. T., \& Umaru, I. (1963). Hausa basic course. Washington, D.C.: Foreign Service Institute.

Holten, E. H., \& Burnett, M. B. (1997). Qualitative research methods. In R. A. Swanson, \& E. F. Holton (Eds.) Human Resource Development Research Handbook: Linking Research and Prentice (pp. 623-649). San Francisco: Berrett-Koehler Publishers.

Ibrahim, S. (2000). Contrastive analysis of gender usage in Hausa and Yorùbá languages. Journal of Method, Language and Literature (JOMLLO), 1(2), 38-49.

Igbokwe, C. O. (2015). Recent curriculum reforms at the basic education level in Nigeria aimed at catching them young to create change. American Journal of Educational Research, 3(1), 31-37.

Jaggar, P. J. (1992). An advanced Hausa reader with grammatical notes and exercises. London: SOAS.

Jaggar, P. J. (1996). Hausa newspaper reader. (Publications of the African Language Project). Kensington, Md.: Dunwoody.

Jaggar, P. (2001). A reference grammar of Hausa. Philadelphia Pennsylvania: John Benjamins.

Keshavarz, M. H. \& Khamis, A. M. (2017). An investigation into pronunciation problems of Hausa speakers, learners of English. International Online Journal of Education and Teaching (IOJET), 4(1), 61-72.

Kraft, C. H. \& Kirk-Greene, A. H. M. (1973). Hausa. (Teach yourself books). London: Hodder and Stoughton.

Kraft, C. H. \& Kraft, M. G. (1973). Introductory Hausa. Berkeley and Los Angeles: University of California Press.

Leedy, P. D. \& Ormrod, J. E. (2005). Practical research: Planning and designing ( $8^{\text {th }}$ Ed.). New Jersey: Pearson Education International.

Mahmoud, B. (2017). Phonological interference of Ebira in the Hausa spoken by Okene speech community. Unpublished M. A. thesis, department of Nigerian languages Bayero University Kano, Nigeria.

Maikanti, S. (2003). A basic course for Hausa learners. Ondo: Complete Printing Press.

Maikanti, S., Shu'aibu, A. \& Uba, A. (2013). A comprehensive Hausa course for L1 \& L2 learners (with exercises). Ibadan: Alafas.

Maikanti, Thai, Burkhardt, Fung, Husain, \& Olúwadọro (2021). Mispronunciation and Substitution of mid-high front and back Hausa Vowels by Yorùbá Native Speakers. REILA: Journal of Research and Innovation in Language, 3(1), 1-16.

Maiunguwa, A. (2015). Perception and production of English fricatives by Hausa speakers. Unpublished M. A. dissertation, University of Malaya, Kuala Lumpur, Malaysia.

Munro, M. J., \& Derwing, T. M. (1995). Foreign accent, comprehensibility, and intelligibility in the speech of second language learners. Language Learning, 45 (1), 73-97.

Mutonya, M. (2008). African Englishes: Acoustic analysis of vowels. World Englishes, 27(3-4), 434449. 
Newman, P. (1995). Hausa tonology: complexities in an 'easy' tone language. In J. Goldsmith (ed.) The Handbook of Phonological Theory (PP. 762-781). Cambridge, MA: Basil Blackwell.

Newman, P. (2000). The Hausa language: An encyclopedic reference grammar. New Haven: Yale University Press.

Nhem, D. (2019). Language learning strategies: A comparative study of young and adolescent Cambodian learners. International Journal of Language and Literary Studies, 1(2), 34-45.

Olubode-Sawe, F. O. (2010). Devising a Yorùbá vocabulary for building construction. PhD dissertation, Adekunle Ajasin University, Akungba-Akoko, Ondo, Nigeria.

Olusola, O. A. (2015). Comparative study of English and Yorùbá morphological system-implication for Nigerian teachers and learners of English. International Journal of English Language and Linguistics Research, 3(4), 1-8.

Olúwadọọ̣, J. O. \& Abiloa, A. (2016). Olukumi: A dialect of Yorùbá in diaspora. Papers in English and Linguistics (PEL), 17, 320-332.

Pillai, S., Mohd, D. Z., Knowles, G. \& Tang, J. (2010). Malaysian English: An instrumental analysis of vowel contrast. World Englishes, 29(2), 159-172.

Qin, Z., \& Mok, P. P. K. (2013). Discrimination of Cantonese tones by speakers of tone and non-tone languages. Kansas Working Papers in Linguistics 34. Retrieved 20 November 2019 from https://kuscholarworks.ku.edu/handle/1808/12864.

Rovai, A. P., Baker, J. D., \& Ponton, M. K. (2013). Social science research design and statistics: A practitioner's guide to research methods and IBM SPSS analysis (2nd ed.). Chesapeake, VA: Water-tree Press.

Salisu, T. \& Grema, M. (2018). A study of automatic assimilation and palatalization in Bade language. Yobe Journal of Language, Literature \& Culture (YOJOLLAC), 6, 102-109.

Samson, G. Y., Abdullahi, A., \& Olagunju, T. S. (2014). Mother tongue interference in the pronunciation of English sounds by Yorùbá language speakers. Academia. Edu. Online retrieved August 23, 2020, 1-6.

Sani, M.A.Z. (2005). An introductory phonology of Hausa with exercises. Kano: Benchmark Publishers Limited.

Sani, M.A.Z. (2007). Tsarin sauti da nahawun Hausa. Ibadan: University Press.

Sharbawi, S. H. (2006). The vowels of Brunei English: An acoustic investigation. World Englishes, 27(3), 247-264.

Shehu, A., \& Njidda, I. U. (2016). Tone realisation in Hausa spoken by Fulfulde native speakers. Online retrieved October 5, 2019. https://www.researchgate.net/publication/319306356.

Sileyew, K. J. (2019). Research design and methodology. In-text mining-analysis, programming and application. Intech Open. DOI: http://dx.doi.org/10.5772/intechopen.85731.

Skinner, N. (1972). Hausa for beginners, 3rd ed. Zaria: Nigeria National Publication Company.

So, C. K., \& Best, C. T. (2010). Cross-language perception of non-native tonal contrast: Effects of native phonological and phonetic influences. Language and Speech, 53(2), 273-293.

So, C. K. (2010). Categorizing Mandarin tones into Japanese pitch-accent categories: The role of phonetic properties. In a presentation at INTERSPECH 2010 satellite workshop on "Second Language Studies: Acquisition, Learning, Education and Technology". Tokyo, Japan.

Sowande, E. J. (1913). A dictionary of Yorùbá language. Lagos: Church Missionary Society Bookshop.

Stella, M. (1985) "Speech synthesis". In F. Fallside \& W. A. Woods (Eds.) Computer Speech Processing (pp. 421-460). Prentice-Hall International: London.

Tailor, P. A. (1992). The OSPREY speech synthesis system. Technical report. Centre for Speech Technology and Research (CSTR). The University of Edinburgh.

Uwaifo, V. O. \& Uddin P. S. O. (2009). Transition from the 6-3-3-4 to the 9-3-4 system of education in Nigeria: An assessment of its implementation on technology subjects, Studies on Home and Community Science, 3(2), 81-86, DOI: 10.1080/09737189.2009.11885280.

Wu, X., Munro, M. J., \& Wang, Y. (2014). Tone assimilation by Mandarin and Thai listeners with and without L2 experience. Journal of Phonetics, 46, 86-100.

Yang, C. (2018). The effect of L1 tonal status on the acquisition of L2 Mandarin tones. International Applied Linguistics, 29, 1-14. 